\title{
Numerical simulation of three-dimensional wind flow patterns \\ over a star dune
}

\begin{abstract}
In this paper, three-dimensional wind flow patterns over a star dune under a longitudinal $\left(\mathrm{W}, 270^{\circ}\right)$ and transverse airflow (ENE, $70^{\circ}$ ) were examined using computational fluid dynamics (CFD) simulations. New surveying techniques of airborne LiDAR and DGPS allow for establishment of the realistic digital model of the star dune. Simulation results were then validated by field measurement using three-dimensional (3D) ultrasonic anemometers combined with arrays of HOBO cup anemometers. Results show that incident flow conditions (longitudinal or transverse airflow) controlled by the angle between incident flow and dune crestline exert great impact on wind flow patterns over the star dune. In periods of longitudinal airflow, a marked feature of wind flow pattern was flow deflection. Wind erosion occurs on both sides of WNW and S sides during W wind and its main effect was to prolong the star dune longitudinally. However, leeside flow separation and reversal were obvious under transverse airflow. The main effect of ENE wind was to promote the upward growth of the star dune. The CFD simulation of 3D wind flows over complex dune system presents great potential for geomorphological research, enabling new insights into complex dune geomorphology and dynamics.
\end{abstract}

Keywords: star dune; CFD; ultrasonic anemometer; airflow; vertical velocity

\section{Introduction}

Star dunes are the largest aeolian bedforms in many modern sand seas (Wasson and Hyde, 1983) and usually distributed in specific geographical areas that have multi-directional wind regimes (Fryberger and Dean, 1979). They are characterized by their pyramidal morphology and radiating sinuous arms, which are a distinctive dune type occupying $8.5 \%$ of the area of global sand sea (Fryberger and Goudie, 1981; Lancaster, 1989b). However, despite their ubiquity in modern sand seas, star dunes 
remain one of the least-studied dune types compared with those such as transverse dunes and linear dunes, and little is known beyond its general characteristics (Lancaster, 1989b; Nielson and Kocurek, 1987; Zhang et al., 2012). This is in part due to the large size of star dunes and their complex control factors (Dong et al., 2013). Therein, the great size of star dunes makes it difficult and even unrealistic to systemically measure their wind flow patterns in the field.

Studies of wind flow over complex topography were mainly focused on hill or valley topography such as Askerverin hill in Scotland and Steptoe Butte in United States by field experiments (e.g. Taylor et al., 1987; Taylor and Teunissen, 1987; Whiteman et al., 1999; Whiteman and Doran, 1993), wind-tunnel measurements (e.g. Britter et al., 2007; Finnigan et al., 1990; Garvey et al., 2005; Gong and Ibbetson, 1989; Sierputowski et al., 1995) or numerical simulations (e.g. Bitsuamlak et al., 2004; Kim et al., 2000; Raithby et al., 1987; Wood, 2000). The impact of complex terrain on wind speed and direction has been particularly well documented, which is significant for wind engineering applications such as dispersion of pollutants (e.g. Apsley and Castro, 1997; Ohba et al., 2002), wind energy resource assessment (e.g. Palma et al., 2008) and ship maneuvering in harbors (e.g. Blocken et al., 2015). In the past 50 years, Computational Fluid Dynamics (CFD) has increasingly been developed and applied as a powerful assessment tool in wind engineering (Blocken, 2014; Blocken et al., 2015). Confidence in the CFD method has been gained by the field and experimental validation of the previously mentioned studies on wind flow over complex topography, although discrepancies still exist (Delgado-Fernandez et al., 2013; Liu et al., 2011; Livingstone et al., 2007).

Recently, CFD models have been widely used to simulate wind flows over aeolian sand dunes (e.g., Parsons et al., 2004; Shi and Huang, 2010) and coastal dune system (e.g., Jackson et al., 2013; Wakes et al., 2010), often aiming to predicting dune movement and growth or sand transport. Furthermore, with the advance of computational techniques and computer technology, CFD modeling of wind flows over sand dunes has no longer been restricted to $2 \mathrm{D}$ conditions, and much progress has been made in the 3D simulations on wind flows over complex dune topography. 
Jackson et al. (2011), for example, successfully compared 3D numerical simulations against field data collected with 3D ultrasonic anemometers at a complex coastal dune system, presenting the potential of CFD tools to improve modeling of flows over complex surfaces. 3D numerical simulations make it possible to capture the real flow pattern and to provide a better assignment the interaction between dune topography and wind flow (Schatz and Herrmann, 2006). Also, they can provide a much more spatial coverage of wind field compared with field studies with extensive instrumentation (Jackson et al., 2011). However, to date, few 3D CFD studies of the flow field around complex dunes (e.g. star dunes) including validation by field measurements have been reported in the literature.

In this study, numerical simulations of 3D wind flow patterns over a star dune (96 $\mathrm{m}$ high) in Dunhuang, China were conducted using the CFD software ANSYS-Fluent. Modeling results were validated by the field data collected using 3D ultrasonic anemometers and arrays of HOBO cup anemometers. This research aims to discuss the potential of 3D CFD simulations to provide insight into the feedback between the complex star dune shape and wind flow and thus to better understand aeolian sediment transport over star dunes and dune dynamics in the future. Also, this study aims to contribute valuable information in the management of complex mega-dunes in the study area to protect the Crescent Moon Spring from burying by wind-blown sand.

\section{Site location}

The specific monitored star dune, with a relative height of $96 \mathrm{~m}$, is located at the Crescent Moon Spring, which is about $5 \mathrm{~km}$ south of the city of Dunhuang, a famous historical and cultural city in Gansu Province, China (Fig.1). This star dune has three arms radiating from the central peak and extending to the $\mathrm{N}\left(5^{\circ}\right), \mathrm{SE}\left(140^{\circ}\right)$, and WSW $\left(250^{\circ}\right)$, respectively; the two adjacent arms constitute the E, S, and WNW dune sides. The east-facing side is a typical avalanche face at angles of $25-32^{\circ}$ and has a slope length of $386 \mathrm{~m}$, and there is a gently sloping plinth ahead of this side. The 
south-facing and north-facing sides have respective slope angles of $15-30^{\circ}$ and $20-30^{\circ}$ and respective slope length of $266 \mathrm{~m}$ and $209 \mathrm{~m}$.

\section{Place Fig. 1 here}

The star dune in this area was formed by three wind directions (Zhang et al., 2000). Westerly winds mainly prevailed in winter, easterly winds were the dominant wind directions in spring and summer, and southerly winds occurred mainly at midnight throughout the year, especially during the months of October to February (Zhang et al., 2016). Using the wind data of 2010.5-2012.4 at the site of A, approximately $800 \mathrm{~m}$ east of the star dune, the drift potential was calculated according to the method reported by Fryberger and Dean (1979). The annual drift potential was $140 \mathrm{VU}$. As expected, there was a clear three-directional wind regime with a primary peak in the western direction (W, WSW, SW) (53.6 VU), a secondary peak in the eastern direction (NE, ENE) (49.8 VU) and a third peak in the southern direction (SSE, S, SSW) (16.1 VU). According to Fryberger's classification of the wind environment standard, this wind regime belongs to a low wind-energy environment with a directional variability (RDP/DP) of 0.16 . Southerly winds, with high frequency and long duration, are a critical local air circulation in this area (Qu et al., 1992; Wang et al., 2005; Zhang et al., 2000), and they constitute the three wind directions with the regional wind regime, contributing to the development of star dunes in a long-time scale.

\section{Methods}

\subsection{Field observation}

For the validation of numerical simulation, field observation on wind flow patterns over the star dune under different wind directions was conducted. Five 3D ultrasonic anemometers (Young Model 81000) mounted at the height of $2 \mathrm{~m}$ were applied to capture vertical and horizontal components of wind over the star dune; twenty-eight HOBO cup anemometers were configured into a series of four arrays to 
measure wind profiles at each site and positioned at 0.2, 0.5, 1 and $2 \mathrm{~m}$ above ground excluding that at the dune crest $(0.5,1,2$ and $3 \mathrm{~m})$. Ultrasonic anemometers were sampled at a frequency of $1 \mathrm{~Hz}$ and all data of $\mathrm{HOBO}$ cup anemometers were collected at 1-min intervals. Wind direction at each site of the star dune was measured using one wind vane at a height of $2 \mathrm{~m}$ above the dune surface except for that at the dune top (3 m).

Monitoring wind flow over the star dune was conducted from 18 March to 24 April 2014, in which both a strong easterly (19 March) and westerly winds (23 April) were measured, of which $\mathrm{W}\left(270^{\circ}\right)$ and $\mathrm{ENE}\left(70^{\circ}\right)$ winds in differernt aiflow features were selected as the scenarios in this study. The incident angle between the $\mathrm{W}$ wind and the WSW arm is smaller than $30-40^{\circ}$, and the airflow is called longitudinal airflow; that between the ENE wind and the SE arm is greater than $30-40^{\circ}$, and the airflow is called transverse airflow (Tsoar, 1983; Wang et al., 2005; Zhang et al., 2000). W and ENE wind directions refered to the 5-min-average wind directions of the HOBO wind vane $(3 \mathrm{~m}$ high) at the top of the star dune. The 5-min-average 3D wind velocities at the ultrasonic anemometers were normalized by the corresponding average wind velocities at the reference sensor $\left(\mathrm{U}_{\mathrm{E} 1}\right)$ to obtain $3 \mathrm{D}$ velocity ratios that could be compared with the CFD modeling results. Data of HOBO anemometers were used as a supplement to those of 3D ultrasonic anemometers to describe the response of wind flows to the star dune morphology.

\subsection{CFD methods}

\subsubsection{Geometry modeling}

The surface terrain data was collected using topographic surveying by airborne LIDAR, which is more suitable for measuring geographically isolated and larger dune systems (Wakes et al., 2010). The interest area (full-scale dune model) with a length of $839 \mathrm{~m}$ and width of $676 \mathrm{~m}$ was selected, where the instrument was also deployed. Meanwhile, at the dune crest lines a DGPS survey was conducted to supplement LIDAR mapping to realistically show the star dune morphology. The numerical 
surface model was established by converting geometric data (regular grid in the $x-y$ with varying height) from the LIDAR and DGPS dataset using ANSYS 10 software (Fig.2). In the case of ENE wind direction the dune model was rotated. For each case, the upstream distance was $10 \mathrm{~h}$ (h, dune height) and the downstream distance was $17 \mathrm{~h}$ to guarantee the full development of the flow field. The dimensions of the computational domain for cases of $\mathrm{W}$ and ENE winds were $4257 \times 1676 \times 500$ and $3954.92 \times 971.44 \times 500 \mathrm{~m}^{3}$, respectively.

\section{Place Fig. 2 here}

\subsubsection{Solution details}

Numerical simulations were carried out by the CFD code ANSYS Fluent (version 12.1), and the SST k- $\omega$ turbulence model was adopted to simulate wind flow and turbulence over the studied star dune. The SST model uses the turbulence/frequency-based model (k- $\omega)$ at the wall and k- $\varepsilon$ in the bulk flow (Menter, 1994). Previous work (e.g., Liu et al., 2011; Shi and Huang, 2010) has established that the SST k- $\omega$ model is a suitable turbulence model in wind flow field simulations.

The SIMPLEC algorithm was used to solve the pressure-velocity coupling. The pressure interpolation scheme was PREssure Staggering Option (PRESTO!). Second-order discretization schemes were applied to the convection and viscous terms of the governing equations. The least-squares cell-based gradient reconstruction scheme was adopted because of its accuracy and speed (ANSYS, 2009).

Grid sensitivity analysis and discretization error estimation were carried out using Grid Convergence Index method (Celiket al., 2008). For each case, an integral parameter, horizontal wind velocity at the height of $2 \mathrm{~m}$ above the ground, which was important to the objective of the simulation study, was investigated. Coarsening and refining was performed with an overall linear factor 1.45 for both cases. Three grids with respective 0.87 (grid3), 2.65 (grid2) and 8.07 million cells (grid1) were selected for the case of W wind, and 0.89 (grid3), 2.71 (grid2) and 8.27 million cells (grid1) for ENE wind. The results of discretization error for horizontal velocity in the case of 
W wind were shown in Table 1, where the horizontal velocities at seven HOBO sites were selected. The numerical uncertainty in the fine-grid solution for the horizontal velocity at these sites was $1.04 \%$. The solution errors in grid 2 were considered within acceptable levels. Consequently, similar grid densities were used for the case of ENE wind.

Place Table 1 here

\subsubsection{Boundary conditions}

The inlet wind speed profile was taken by Eq. (1), and a reference wind velocity of $9 \mathrm{~m} \mathrm{~s}^{-1}$ at the height of $2 \mathrm{~m}$ was assigned, which was equal to the measured wind data. The approaching wind profile was judged to be similar to flow over open nature terrain in the simulation for simplifications (Jackson et al., 2011; Wakes et al., 2010). Values of aerodynamic roughness length $z_{0}$ and friction velocity in this simulation were $0.87 \mathrm{~mm}$ and $0.48 \mathrm{~m} \mathrm{~s}^{-1}$, respectively, which were estimated from the wind profiles at reference arrays of anemometers using the method reported by Bauer et al. (1992). A pressure-outlet boundary with a pressure gradient of zero was set at the end of the domain, and for the top boundary the inlet velocity at its height was assigned.

$$
U_{z}=u_{*} \kappa / \ln \left(z / z_{0}\right)
$$

where $U_{z}$ is the wind speed at $\mathrm{z}(\mathrm{m})$ height, $\kappa=0.4$ is the von Karman coefficient, $u_{*}$ is the friction velocity, $z_{0}$ the aerodynamic roughness length. The turbulent kinetic energy $(k)$ and the specific dissipation rate $(\omega)$ were calculated according to the respective formula: $\mathrm{k}=1.5\left(U_{\text {avg }} \mathrm{I}\right)^{2}$

and $\omega=k^{0.5} / \iota C_{\mu}^{0.25}$

where $U_{a v g}$ is the mean flow velocity, and in the simulation values of $U_{\text {avg }}$ for both $\mathrm{W}$ and ENE winds were $14 \mathrm{~m} \cdot \mathrm{s}^{-1}$; I is the turbulence intensity, $\mathrm{l}$ is the turbulence length scale; $\mathrm{C}_{\mu}$ is an empirical constant with a value of 0.09 . Detailed formulas for calculation of these parameters can be found in the theory guide of Ansys Fluent (ANSYS, 2009). 
The volume was meshed using Tri-pave on the surface and Tet-hybrid volumes within Gambit (version 2.4). The global mesh size in the domain and near the surface of the star dune was resolved based on the minimum dimensionless distance from the wall or the location of the wall adjacent cell $\left(\mathrm{y}^{+}\right)$value, with a main target to obtain the desired level of accuracy and flow details near the dune surface. A standard wall function with a roughness modification in Fluent 6.2 was used. The input values of the sand-grain roughness height $k_{\mathrm{S}}(\mathrm{m})$ and the roughness constant $C_{\mathrm{S}}$ were determined using their consistency relationship with the aerodynamic roughness length $z_{0}$ derived by Blocken et al. (2007) (Eq. (4)). A default value of 0.5 was used for $C \mathrm{~s}$, and thus the selected value of $k_{\mathrm{S}}$ was $0.017 \mathrm{~m}$ for an average $\mathrm{z}_{0}$ of $0.00087 \mathrm{~m}$ in this simulation calculated from field data. As presented in CFD codes such as Fluent 6.2, the radius of the cell at the dune surface $\left(y_{\mathrm{p}}\right)$ should not be smaller than the roughness height $\left(k_{\mathrm{S}}\right)$. The heights of wall-adjacent cells $\left(y_{\mathrm{p}}\right)$ were variable from 0.05 $\mathrm{m}$ at the inlet region to about $0.02 \mathrm{~m}$ near the dune model. A growth rate of 1.25 was applied to concentrate more cells around the dune surface. The wall adjacent cell $\mathrm{y}^{+}$ values ranged from 150 to 650 in this simulation, ensuring the center of wall adjacent cell was placed in the logarithmic layer which was valid above about $\mathrm{y}^{+}=30$ up to $\mathrm{y}^{+}=500-1000$ (Blocken et al., 2007).

$$
k_{S}=9.793 \mathrm{z}_{0} / C_{S}
$$

\section{Results}

\subsection{Field observation}

\subsubsection{Wind flow field under $W$ wind}

Wind data measured by HOBO cup anemometers were here used to qualitatively describe the response of wind flow to the star dune morphology. Figure 3 displays the wind flow pattern of the star dune during westerly wind. In periods of westerly wind, attached and deflected flows occurred at both WNW and S sides as the incident angle between wind direction and the $\mathrm{W}$ arm was $20^{\circ}$, which was a longitudinal airflow. 
Wind flows radiated outward at both dune toes of WNW (WSW wind) and S sides (WNW wind) while wind directions showed inward convergence components at upper one-third section of dune sides (WNW wind on WNW side and WSW wind on $\mathrm{S}$ side) in addition to the component of $\mathrm{W}$ direction, which was similar to the results of topographically induced onshore steering from the direction of alongshore to oblique incident flows over foredunes reported by Walker et al. (2009). The average clockwise angle deviating from the incident airflow reached $18.4^{\circ}$. Meanwhile, flow separation and reversal presented on the lee side of the star dune (E side). Ultrasonic anemometers $\left(\mathrm{U}_{\mathrm{E} 2}\right.$ and $\left.\mathrm{U}_{\mathrm{E} 3}\right)$ showed that the secondary circulation developed on the $\mathrm{E}$ side was a return flow with main wind directions of ESE and E, thus most probably in the form of helical vortex for the occurrence of deviation from $\mathrm{E}$ wind direction-ESE. Data of ultrasonic anemometers $\left(\mathrm{U}_{\mathrm{E} 2}\right.$ and $\left.\mathrm{U}_{\mathrm{E} 3}\right)$ showed that at the middle and toe of the east-oriented side the average elevation angels of the vortex were $14.7^{\circ}$ and $22.1^{\circ}$, respectively.

\section{Place Fig. 3 here}

Wind velocities measured by HOBO cup anemometers were normalized with respect to the anemometer maintained at the dune crest with a height of $3 \mathrm{~m}$. The pattern of wind speeds in periods of westerly wind was characterized by the accelerating flows on both WNW and S sides, while the amplifying effect was slight with the average velocity ratio (vr) changing from approximately 0.6 at the toe to 0.8 at the upper one-third section of these dune slopes. Meanwhile, the E side of the star dune was a zone of low and variable wind velocities, in which velocities were 0.2-0.3 of those at the reference anemometer. In this case, sands were transported obliquely along both north and south-facing slopes, causing the longitudinal dune prolongation and crest height decrease.

\subsubsection{Wind flow field under ENE wind}

During ENE wind, the incident angle between the airflow and the north and 
southeast arms was 65 and $70^{\circ}$, respectively, which was a transverse airflow, and flow separation and reversal occurred on both the north and southeast arms of the star dune (Fig. 4). These secondary circulations were also return airflows which indicated from the positive flow elevation angles in $3 \mathrm{D}$ ultrasonic anemometers in the lee side of these arms $\left(U_{N}\right.$ and $\left.U_{S}\right)$. The occurrence of the reverse vortex on the lee side of these arms plays an important role in sharpening or heightening the ridges of star dunes. At the star dune crest, the convergence of the windward wind-blown sand on stoss slope and reverse one on lee slope resulted in sand accumulation, causing vertical ridge growth. With gradual vertical development of the ridge, the angle of repose was exceeded, and sand avalanching took place at the crest down the lee side, causing the crest to advance. Besides, topographically induced clockwise steering from the direction of incident flow also occurred on the windward E side from the dune toe to the upper one-third section. The average clockwise angle deviating from the incident airflow reached $17.9^{\circ}$, which was smaller than that on the windward WNW side during $\mathrm{W}$ wind, indicating that the deflection of flow over the star dune is more obvious for longitudinal airflow than transverse airflow.

\section{Place Fig. 4 here}

In periods of ENE wind, beyond the dune toe, near-surface wind speeds increase toward the crest due to streamline compression and flow acceleration. For example, the average velocity ratio at the dune toe of $\mathrm{E}$ side was 0.47 , while the $\mathrm{vr}$ at the interdune area was 0.62 ; at the upper one-third section, it increased to approximately 2.1 times that at the dune toe. Thus, the amplifying effect of transverse airflow was more remarkable than longitudinal airlflow. Meanwhile, the WNW and S lee sides of the star dune were within zones of low and variable wind velocities, in which velocity ratios ranged from 0.25 to 0.27 of those at the reference anemometer mounted at the upper one-third section of the E side. In this case, transverse airflow plays an important role of the height growth of the star dune.

\subsection{CFD simulations}




\subsubsection{Wind flow field under $W$ wind}

In periods of westerly wind, there was a strong separation of flow at the crest of north and southeast arms of the star dune (Fig.5-a), and a well-developed secondary circulation in the leeside of these arms swept sand along the avalanche face towards the southeast arm, which was also consistent with the measured wind rose in the site of $\mathrm{H}_{\mathrm{E} 1}$ and the result reported by Lancaster (1989a). This circulation was a return flow indicating from the positive elevation angles in Fig.5-b at sites of $\mathrm{U}_{\mathrm{E} 2}$ and $\mathrm{U}_{\mathrm{E} 3}$ in the eastern leeside, which was in agreement with the measurement result. In addition, the simulation results also show that vertical velocity was mainly determined by the angle between the incident flow and the dune ridge line (incident angle). For example, the incident angle between westerly wind and the WSW crestline was approximately $20^{\circ}$, and the vertical velocities along this ridge line were in the range of $2.47-3.64 \mathrm{~m} \mathrm{~s}^{-1}$; in contrast, the incident angle between westerly wind and the $\mathrm{N}$ crestline was approximately $85^{\circ}$, and the vertical velocities reached $5.96-7.12 \mathrm{~m} \mathrm{~s}^{-1}$, which was 2.0-2.4 times of those on the WSW crestline (Fig.5-b). Under the effect of longitudinal airflow, the vertical airflow occurred on the upper WSW arm, which is consistent with the results of the near-surface flow field of a longitudinal dune reported by Tsoar et al. (1985) and Bristow et al. (2000).

Place Fig. 5 here

\subsubsection{Wind flow field under ENE wind}

Figure 6 shows the simulated wind flow field of the star dune during ENE wind. In periods of ENE wind, wind speeds at the northeast bottom of the E sidedecreased compared with that of the incident airflow and a stagnation zone occured due to the barrier effect of east-oriented side (Fig.6-a). However, wind speeds increased clearly from the upper one-third section of E side toward the top of the star dune, reaching a maximum near the dune top. In addition, one clockwise vortex occurred on the $\mathrm{S}$ side, which could also be indicated from the measured wind direction change from the 
location of $\mathrm{H}_{\mathrm{S} 2}$ to $\mathrm{H}_{\mathrm{S} 1}$.

The flow separation and reversal in the WNW and S lee sides and development of strong vertical airflows near windward dune crest lines were the marked features of the flow field of the star dune during ENE wind. The strength of the vertical airflow was closely related to the locations on the E side. The lower, middle, and top locations of the E side corresponded to the vertical airflow initiation, development, and culmination zones, respectively, in which the vertical velocities increased from 2.01-3.21, 3.64-4.80 and 5.96-7.12 $\mathrm{m} \mathrm{s}^{-1}$ (Fig.6-b). The airflows around the bottom of $\mathrm{N}$ and SE crestlines converged at the WSW crestline, which was important for the development of WSW arm.

\section{Place Fig. 6 here}

\section{Discussion}

\subsection{Comparison between the measured and simulated results}

Values of wind speed ratio and wind direction were selected to make the comparison between the measured and simulated results (Fig. 7). On the whole for the majority of the HOBO measurement sites the simulated velocity ratios compared well with the field data (Fig. 7a, b). The most apparent deviation occurred at the toe of the $\mathrm{S}$ side during ENE wind, in which the measured velocity ratio was larger than the simulated value (Fig. 7b). The reason lay in that in the field the funneling effect between the star dune and the southern mega-dune increased the wind velocity at the site of $\mathrm{H}_{\mathrm{S} 2}$ as reported by Zhang et al. (2016).

3D ultrasonic anemometers were better to present topographically induced variations in near-surface flow (Walker et al., 2009), so the measured 3D wind speed data was also used to compared with those of numerical simulations. Figure $7 \mathrm{c}, \mathrm{d}$ shows the measured as well as the simulated $3 \mathrm{D}$ velocity ratios (reference sensor, $\mathrm{U}_{\mathrm{E} 1}$ ) at $2 \mathrm{~m}$ above the dune surface at locations of $\mathrm{U}_{\mathrm{E} 2}, \mathrm{U}_{\mathrm{E} 3}, \mathrm{U}_{\mathrm{N}}$, and $\mathrm{U}_{\mathrm{S}}$ under the two incident flow conditions. It can be seen from Fig. 7c, d that the simulated 3D wind 
speed ratios were consistent with those measured though values of $v_{\mathrm{s}}$ were slightly smaller than $\mathrm{vr}_{\mathrm{m}}$, and the $R^{2}$ of the regression equation of the simulated and measured 3D velocity ratios were 0.865 and 0.859 for westerly and easterly wind, respectively. Despite diversity in wind velocities at the reference sensor, the standard deviations were very low, which indicated small variability of individual vr with respect to the mean value given here.

\section{Place Fig. 7 here}

The numerically simulated wind directions were generally situated within the standard deviations of the measurements (Table 2). However, at the upper one-third section of the windward slope, the measured wind direction deviated from the simulated one by $13.1^{\circ}$ and $7.5^{\circ}$ in cases of $\mathrm{W}$ and ENE winds, respectively, and vectors show topographically induced clockwise steering from the direction of incident flow, which did not present in the simulation.

\section{Place Table 2 here}

\subsection{Geomorphological implications of wind flow patterns}

Westerly and easterly winds were the two predominant strong winds in the study area. For all the two cases, the flow patterns were stagnation zones at the windward toe, flow accelerations on the windward slope, maximum velocities at the crest line, and reverse zones in the leeward. Wind flow patterns presented in this study can be used to predict erosion and deposition patterns over the star dune, which is very significant for the conservation of Crescent Moon Spring which has survived for thousands of years (Qu et al., 2013). According to the studies of Zhang et al. (2013) and Han et al. (2015), the threshold velocity at the study area was approximately $5 \mathrm{~m}$ $\mathrm{s}^{-1}$ at a height of $2 \mathrm{~m}$. Bagnold (1941) demonstrated that sand transport rate $(q)$ was positively related to the cube of wind velocities above the threshold for sediment entrainment, and thus the sand transport rate can be expressed by the following equation in the study area: 


$$
q \propto\left(u_{2 m}-5\right)^{3}
$$

where $u_{2 m}$ refers to wind speed at a height of $2 \mathrm{~m}$. According to Fig. 5, wind velocities at a height of $2 \mathrm{~m}$ during $\mathrm{W}$ wind on the WNW and S sides were larger than $6.61 \mathrm{~m} \mathrm{~s}^{-1}$, and thus sand transport or sand erosion occurred on both the two sides, and sand deposition occurred on the E side. As a longitudinal airflow, the main effect of W wind was to prolong the star dune, and that is, sands were transported obliquely along a stoss and a lee slope, causing the longitudinal migration and decreasing height of crest. The WSW longitudinal ridge of the star dune was formed by longitudinal airflow, from which the morphology of star dune developed (Zhang et al., 2016).

However, the effect of easterly wind on development of the star dune was different from that of westerly wind. As a transverse airflow for north and southeast arm with the respective incident angles of $65^{\circ}$ and $70^{\circ}$, the main contribution of easterly wind was to heighten the star dune. Fig. 6 showed that wind velocities at a height of $2 \mathrm{~m}$ on the E side during ENE wind were larger than $5.59 \mathrm{~m} \mathrm{~s}^{-1}$, while they were below $3.00 \mathrm{~m} \mathrm{~s}^{-1}$ at the most sections of $\mathrm{S}$ and WNW lee sides. Thus, during ENE wind, wind erosion mainly occurred on the windward E side, and the strong airflow transported sand particles from the toe of E side to the crest, and sand deposition occurred near the leeward WNW and S sides. At the star dune crest, the convergence of the windward sand stream on the stoss slope and reverse sand stream on the lee slope leads to sand accumulation, causing vertical growth of dune ridges. Besides, wind-blown sand around the bottom of $\mathrm{N}$ and SE crestlines with wind velocities at the height of $2 \mathrm{~m}$ ranging from 5.59-10.8 $\mathrm{m} \mathrm{s}^{-1}$ converged at the WSW crestline, which played an important role in the development of WSW arm. Additionally, the local air circulation-southerly wind played an important role in the formation and development of north arm of the star dune though the flow field was not simulated and its effect could only be presented in the long run (Zhang et al., 2016). Thus, interactions between dune form and airflow as winds change direction seasonally play a major role in the formation of this dune type as reported by Lancaster (1989a). 


\section{Conclusions}

Computational fluid dynamics (CFD) simulations on three-dimensional wind flow patterns over a star dune were performed in two cases of a longitudinal (W, $270^{\circ}$ ) and transverse airflow (ENE, $70^{\circ}$ ), two predominant wind directions in the study area. Results show that topographic steering and forcing effects of the star dune cause the local properties and vectors of flow to deviate significantly from the regional wind in response to change of incident flow directions. The main occlusions are:

1) Star dunes exhibit the dynamic characteristics of transverse and longitudinal dunes. Seasonally variable wind directions exert considerable influence on the development of the star dune. The occurrence of erosion and deposition of a dune arm depends upon the incident angle between the wind direction and dune crest line.

2) In periods of longitudinal airflow-westerly wind, flow separation and reversal showed on the leeside of both the WNW and S arms, and the helical vortex swept sand along the avalanche face in east-oriented side toward the south arm. Field measurement showed that the vortex was a return flow with respective elevation angels of $14.7^{\circ}$ and $22.1^{\circ}$ at the middle and toe of the east-oriented side. In this flow pattern, the star dune mainly migrated longitudinally like a longitudinal sand dune.

3) In periods of transverse airflow-easterly wind, strong vertical airflow developed on both the north and southeast arms. The convergence of wind-blown sand from windward and lee slopes at the crest prompted sand accumulation there, causing the vertical growth of crest lines. In this flow pattern, the star dune mainly migrated transversely like a transverse dune.

The effect of varying surface roughness on the wind flow, due to vegetation cover and buildings around the star dune needs to be considered in future work. Work is continuing into the CFD simulation of complex mega-dunes in the study area and flow fields in a larger spatial scale with computational power enhancing. 


\section{Acknowledgements}

This work was funded by the National Science Foundation of China (Grant No.41271023; No.41271216). We thank the Crescent Moon Spring Management Agency for their help in the field work. The authors are grateful to two anonymous reviewers for their insightful comments and suggestions.

\section{References}

ANSYS, Inc., 2009. ANSYS FLUENT 12.0 Theory Guide.

Apsley, D.D., Castro, I.P., 1997. Numerical modelling of flow and dispersion around cinder cone butte. Atmospheric Environment, 31(7), 1059-1071.

Bagnold, R.A., 1941. The Physics of Blown Sand and Desert Dunes. Methuen, London.

Bauer, B.O., Sherman, D.J., Wolcott, J.F., 1992. Sources of Uncertainty in Shear Stress and Roughness Length Estimates Derived from Velocity Profiles*. The Professional Geographer 44, 453-464.

Bitsuamlak, G.T., Stathopoulos, T., Eacute, C., dard, 2004. Numerical Evaluation of Wind Flow over Complex Terrain: Review. Journal of Aerospace Engineering 17, 135-145.

Blocken, B., Stathopoulos, T., Carmeliet, J., 2007. CFD simulation of the atmospheric boundary layer: wall function problems. Atmospheric Environment 41, 238-252.

Blocken, B., 2014. 50 years of Computational Wind Engineering: Past, present and future $i$. Journal of Wind Engineering \& Industrial Aerodynamics 129, 69-102.

Blocken, B., Hout, A.V.D., Dekker, J., Weiler, O., 2015. CFD simulation of wind flow over natural complex terrain: Case study with validation by field measurements for Ria de Ferrol, Galicia, Spain. Journal of Wind Engineering \& Industrial Aerodynamics 147, 43-57.

Bristow, C., Bailey, S., Lancaster, N., 2000. The sedimentary structure of linear sand dunes. Nature, 406(6791), 56-59.

Britter, R.E., Hunt, J.C.R., Richards, K.J., 2007. Air flow over a two-dimensional hill: Studies of velocity speed-up, roughness effects and turbulence. Quarterly Journal of the Royal Meteorological Society 107, 91-110.

Delgado-Fernandez, I., Jackson, D.W.T., Cooper, J.A.G., Baas, A.C.W., Beyers, J.H.M., Lynch, K., 2013. Field characterization of three-dimensional leeside airflow patterns under offshore winds 
at a beach - dune system. Journal of Geophysical Research Earth Surface, 118(2), 706-721.

Dong, Z., Zhang, Z., Qian, G., Luo, W., Lv, P., Lu, J., 2013. Geomorphology of star dunes in the southern Kumtagh Desert, China: control factors and formation. Environmental earth sciences, 69(1), 267-277.

Finnigan, J.J., Raupach, M.R., Bradley, E.F., Aldis, G.K., 1990. A wind tunnel study of turbulent flow over a two-dimensional ridge. Boundary-Layer Meteorology 50, 277-317.

Fryberger, S., Goudie, A., 1981. Arid geomorphology Progress in Physical Geography, 5, 420-428.

Fryberger, S.G., Dean, G., 1979. Dune forms and wind regime. A Study of Global SandSeas. U.S. Government Printing Office, Washington D.C., pp. 137-169.

Garvey, B., Castro, I.P., Wiggs, G., Bullard, J., 2005. Measurements of Flows Over Isolated Valleys. Boundary-Layer Meteorology 117, 417-446.

Gong, W., Ibbetson, A., 1989. A wind tunnel study of turbulent flow over model hills. Boundary-Layer Meteorology 49, 113-148.

Han, Q., Qu, J., Dong, Z., Zhang, K., Zu, R., 2015. Air density effects on aeolian sand movement: Implications for sediment transport and sand control in regions with extreme altitudes or temperatures. Sedimentology 62, 1024-1038.

Jackson, D., Cruz-Avero, N., Smyth, T., Hernandez-Calvento, L., 2013. 3D airflow modelling and dune migration patterns in an arid coastal dune field. Journal of Coastal Research, 1301-1306.

Jackson, D.W.T., Beyers, J.H.M., Lynch, K., Cooper, J.A.G., Baas, A.C.W., Delgado-Fernandez, I., I., D.F.I., 2011. Three-dimensional wind flow behaviour over coastal dune morphology under offshore winds using Computational Fluid Dynamics (CFD) and ultrasonic anemometry. Earth Surface Processes \& Landforms, 36, 1113-1124.

Lancaster, N., 1989a. The dynamics of star dunes: an example from the Gran Desierto, Mexico. Sedimentology, 36(2), 273-289.

Lancaster, N., 1989b. Star dunes. Progress in Physical Geography, 13(1), 67-91.

Liu, B., Qu, J., Zhang, W., Qian, G., 2011. Numerical simulation of wind flow over transverse and pyramid dunes. Journal of Wind Engineering \& Industrial Aerodynamics, 99(8), 879-888.

Livingstone, I., Wiggs, G.F.S., Weaver, C.M., 2007. Geomorphology of desert sand dunes: A review of recent progress. Earth-Science Reviews, 80(s 3-4), 239-257.

Menter, F.R.,1994. Two-equation eddy-viscosity turbulence models for engineering applications, Aiaa 
Journal, 32(8), 1598-1605.

Nielson, J., Kocurek, G., 1987. Surface processes, deposits, and development of star dunes: Dumont dune field, California. Geological Society of America Bulletin, 99(2), 177-186.

Ohba, R., Hara, T., Nakamura, S., Ohya, Y., Uchida, T., 2002. Gas diffusion over an isolated hill under neutral, stable and unstable conditions. Atmospheric Environment 36, 5697-5707.

Palma, J.M.L.M., Castro, F.A., Ribeiro, L.F., Rodrigues, A.H., Pinto, A.P., 2008. Linear and nonlinear models in wind resource assessment and wind turbine micro-siting in complex terrain. Journal of Wind Engineering \& Industrial Aerodynamics 96, 2308-2326.

Parsons, D.R., Walker, I.J., Wiggs, G.F.S., 2004. Numerical modelling of flow structures over idealized transverse aeolian dunes of varying geometry. Geomorphology, 59, 149-164.

Qu, J., Cao, S., Li, G., Niu, Q., Qi, F., 2013. Conservation of natural and cultural heritage in Dunhuang, China. Gondwana Research 26, 1216-1221.

Qu, J., Ling, Y., Zhang, W., Lu, j., 1992. Preliminary observation and study on the formation mechanism of pyramid dune (in Chinese with English abstract). Journal of Desert Research, 12(4), 20-28.

Raithby, G.D., Stubley, G.D., Taylor, P.A., 1987. The Askervein hill project: A finite control volume prediction of three-dimensional flows over the hill. Boundary-Layer Meteorology 39, 247-267.Schatz, V., Herrmann, H.J., 2006. Flow separation in the lee side of transverse dunes: A numerical investigation. Geomorphology, 81(s1-2), 207-216.

Shi, F., Huang, N., 2010. Computational simulations of blown sand fluxes over the surfaces of complex microtopography. Environmental Modelling \& Software, 25(3), 362-367.

Sierputowski, P., Ostrowski, J., Cenedese, A., 1995. Experimental study of wind flow over the model of a valley. Journal of Wind Engineering \& Industrial Aerodynamics 57, 127-136.

Taylor, P.A., Mason, P.J., Bradley, E.F., 1987. Boundary-layer flow over low hills. Boundary-Layer Meteorology 39, 107-132.

Taylor, P.A., Teunissen, H.W., 1987. The Askervein Hill project: Overview and background data. Boundary-Layer Meteorology 39, 15-39.

Tsoar, H., 1983. Dynamic processes acting on a longitudinal (seif) sand dune. Sedimentology, 30(4), $567-578$.

Tsoar, H., Rasmussen, K.R., Sørensen, M., Willetts, B.B., 1985. Laboratory studies of flow over dunes. 
International Workshop on the Physics of Blown Sand, Memoirs, 8, 327-350.

Wakes, S.J., Maegli, T., Dickinson, K.J., Hilton, M.J., 2010. Numerical modelling of wind flow over a complex topography. Environmental Modelling \& Software, 25(2), 237-247.

Walker, I.J., Hesp, P.A., Davidson-Arnott, R.G., Bauer, B.O., Namikas, S.L., Ollerhead, J., 2009. Responses of three-dimensional flow to variations in the angle of incident wind and profile form of dunes: Greenwich Dunes, Prince Edward Island, Canada. Geomorphology, 105(1), 127-138.

Wang, T., Zhang, W., Dong, Z., Qu, J., Jing, Z., Wang, W., Feng, J., 2005. The dynamic characteristics and migration of a pyramid dune. Sedimentology, 52(3), 429-440.

Wasson, R.J., Hyde, R., 1983. Factors determining desert dune type. Nature, 304(5924), 337-339.

Whiteman, C.D., Bian, X., Sutherland, J.L., 1999. Wintertime Surface Wind Patterns in the Colorado River Valley. Journal of Applied Meteorology 38, 1118-1130.

Whiteman, C.D., Doran, J.C., 1993. The Relationship between Overlying Synoptic-Scale Flows and Winds within a Valley. Journal of Applied Meteorology 32, 1669-1682.

Wood, N., 2000. Wind Flow Over Complex Terrain: A Historical Perspective and the Prospect for Large-Eddy Modelling. Boundary-Layer Meteorology 96, 11-32.

Zhang, D., Narteau, C., Rozier, O., Courrech du Pont, S., 2012. Morphology and dynamics of star dunes from numerical modelling. Nature Geosci, 5(7), 463-467.

Zhang, K., Qu, J., Niu, Q., Jing, Z., An, Z., 2013. Characteristics of wind-blown sand in the region of the Crescent Moon Spring of Dunhuang, China. Environmental Earth Sciences 70, 3107-3113.

Zhang, W., Qu, J., Dong, Z., Li, X., Wang, W., 2000. The airflow field and dynamic processes of pyramid dunes. Journal of arid Environments, 45(4), 357-368.

Zhang, W., Qu, J., Tan, L., Jing, Z., Bian K., Niu, Q., 2016. Environmental dynamics of a star dune. Geomorphology, 273, 28-38. 
Fig. 1 Location of the studied star dune, the layout of 3D ultrasonic (circle) and HOBO anemometers (rectangle) and the sand drift potential rose at the site of A during 2010.5-2012.4.

Fig. 2 Detailed topographic mesh surface from the merger of LIDAR and DGPS data.

Fig. 3 The measured wind flow pattern over the star dune in periods of westerly wind. $\mathrm{H}_{\mathrm{T}}(3 \mathrm{~m}$ high) and $\mathrm{U}_{\mathrm{T}}$ were reference sensors for wind speed data of $\mathrm{HOBO}$ and $3 \mathrm{D}$ ultrasonic anemonmeters, respectively, figures of wind roses in these two sites were not shown in this figure, and others were consistent with locations in Fig.1.

Fig. 4 The measured wind flow pattern over the star dune in periods of easterly wind. $\mathrm{H}_{\mathrm{El}}(2 \mathrm{~m} \mathrm{high})$ and $\mathrm{U}_{\mathrm{T}}$ were reference sensors for wind speed data of $\mathrm{HOBO}$ and $3 \mathrm{D}$ ultrasonic anemonmeters, respectively, figures of wind roses in these two sites were not shown in this figure, and others were consistent with locaitons in Fig.1.

Fig. 5 Simulated horizontal (a), vertical velocities (b) and vectors during westerly wind at a height of $2 \mathrm{~m}$ above the dune surface (the inlet velocity at a height of $2 \mathrm{~m}$ was $9 \mathrm{~m} \mathrm{~s}^{-1}$ ). Vectors were in a skip of 7 , and dashed lines represented the dune crests.

Fig. 6 Simulated horizontal (a), vertical velocities (b) and vectors during easterly wind at a height of $2 \mathrm{~m}$ above the dune surface (the inlet velocity at a height of $2 \mathrm{~m}$ was $9 \mathrm{~m} \mathrm{~s}^{-1}$. Vectors were in a skip of 7, and dashed lines represented the dune crests. The legend in Fig. 6a was the opposite compared with that in Fig. 5a due to inflow direction from negative x-axis.

Fig. 7 Comparison between the measured and simulated velocity ratios at measurements of HOBO (a, b) and ultrasonic anemometers (c, d). $\mathrm{u}_{\mathrm{ref}}$ refers to wind speed at $\mathrm{H}_{\mathrm{T}}$ at a height of $2 \mathrm{~m} . \mathrm{vr}_{\mathrm{m}}$ and $\mathrm{vr}_{\mathrm{s}}$ refer to the respective measured and simulated $3 \mathrm{D}$ wind speed ratios (reference sensor, $\mathrm{U}_{\mathrm{E} 1}$ ) at $2 \mathrm{~m}$ above the dune surface at locations of $\mathrm{U}_{\mathrm{E} 2}, \mathrm{U}_{\mathrm{E} 3}, \mathrm{U}_{\mathrm{N}}$, and $\mathrm{U}_{\mathrm{S}}$ under the two incident flow conditions. Horizontal and vertical error bars represent the standard deviations of 5-min-average 3D speed ratios and of those in simulitions under reference inlet velocity of $9 \mathrm{~m} \mathrm{~s}^{-1}$. 
Figure 1

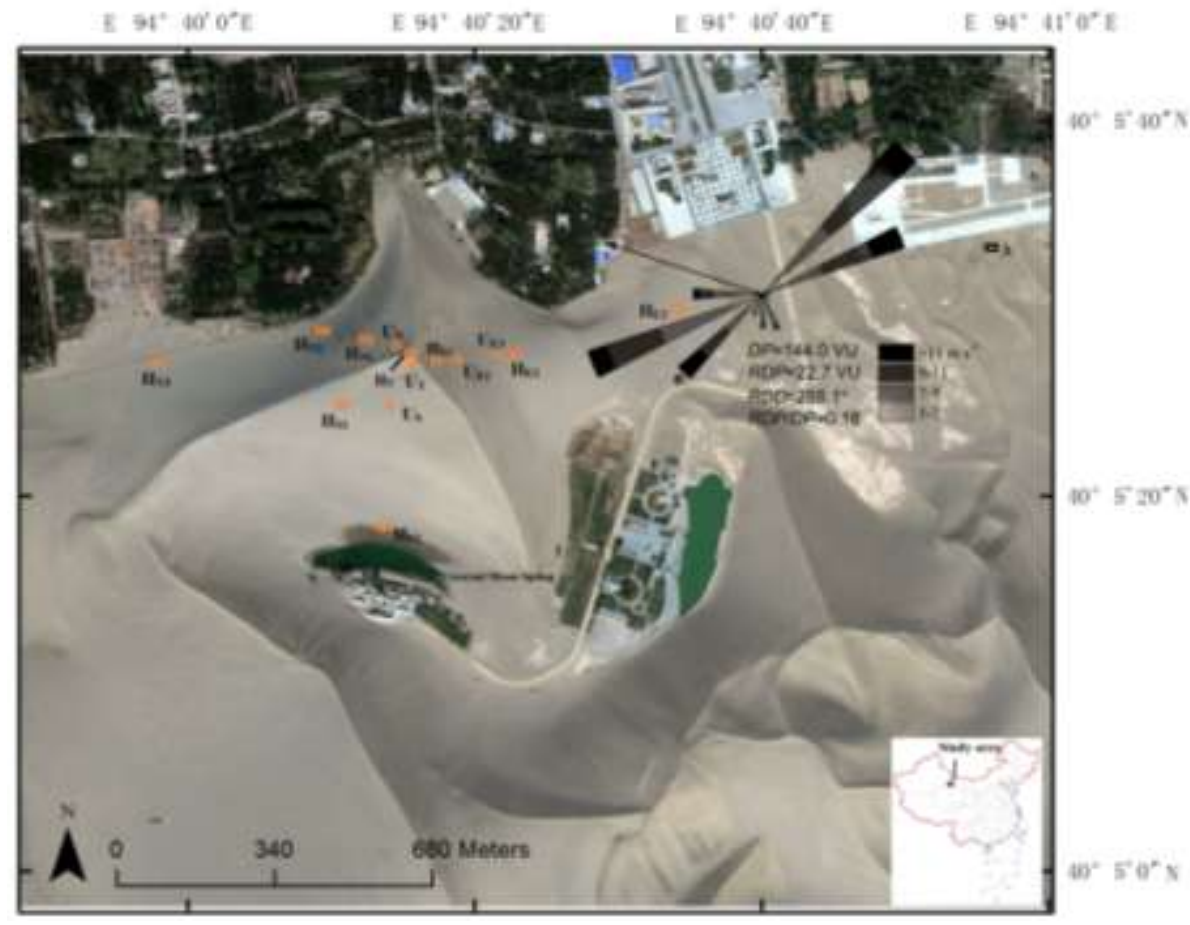

Figure 2

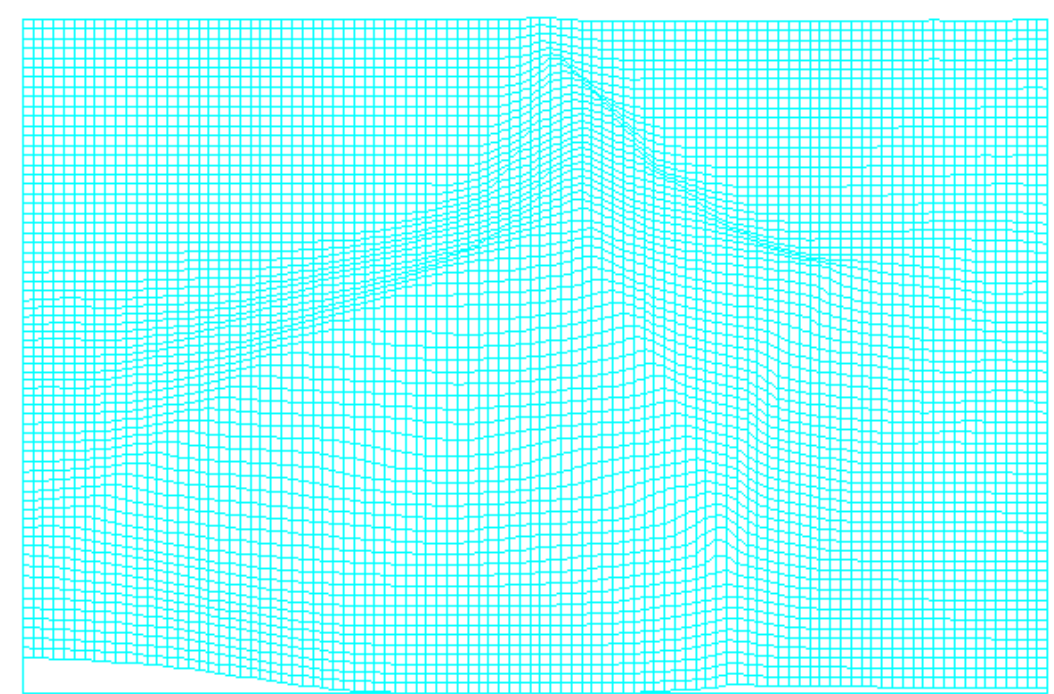


Figure 3

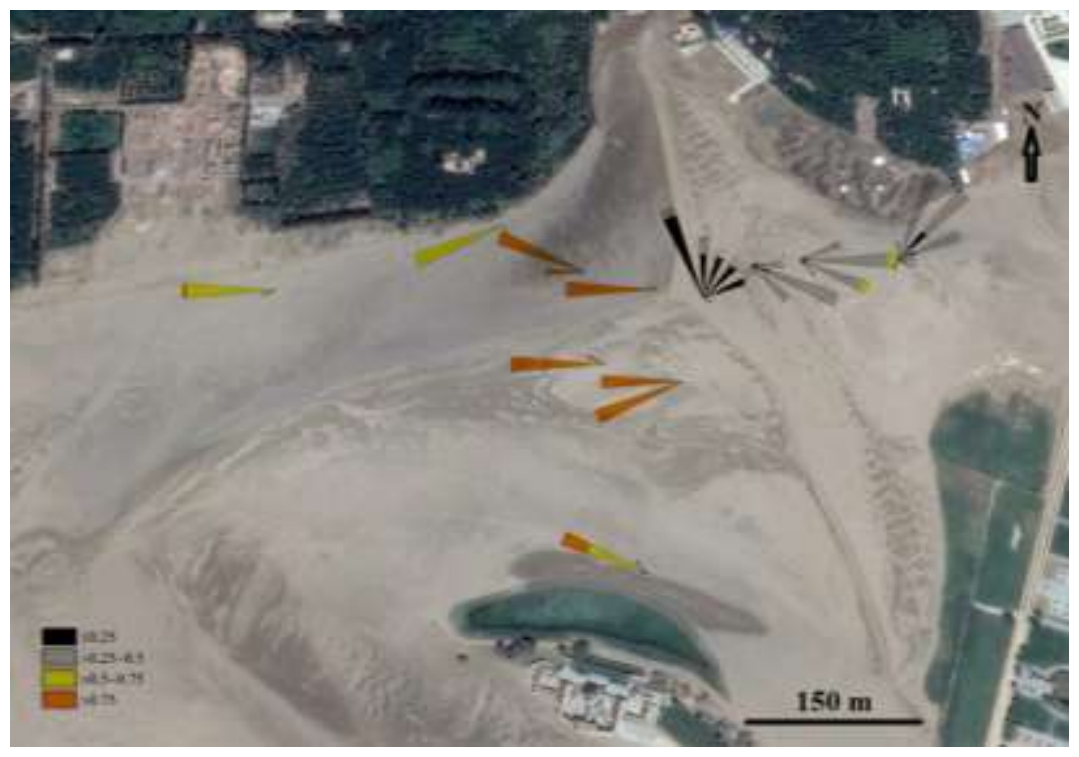

Figure 4

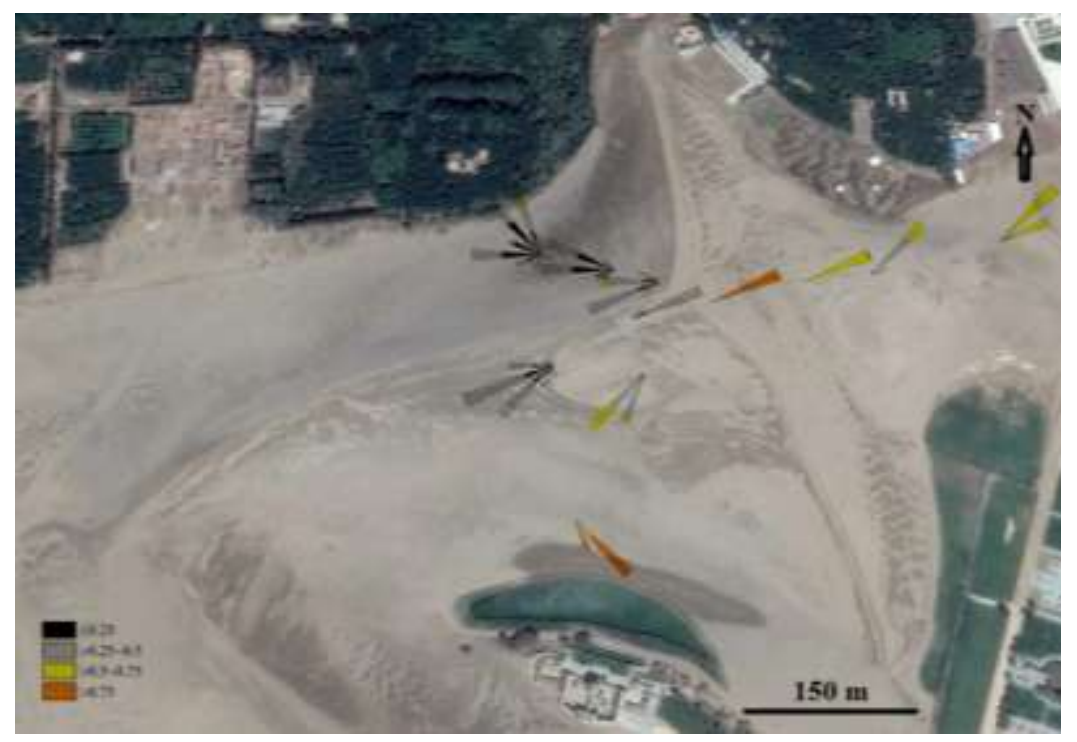


Figure 5

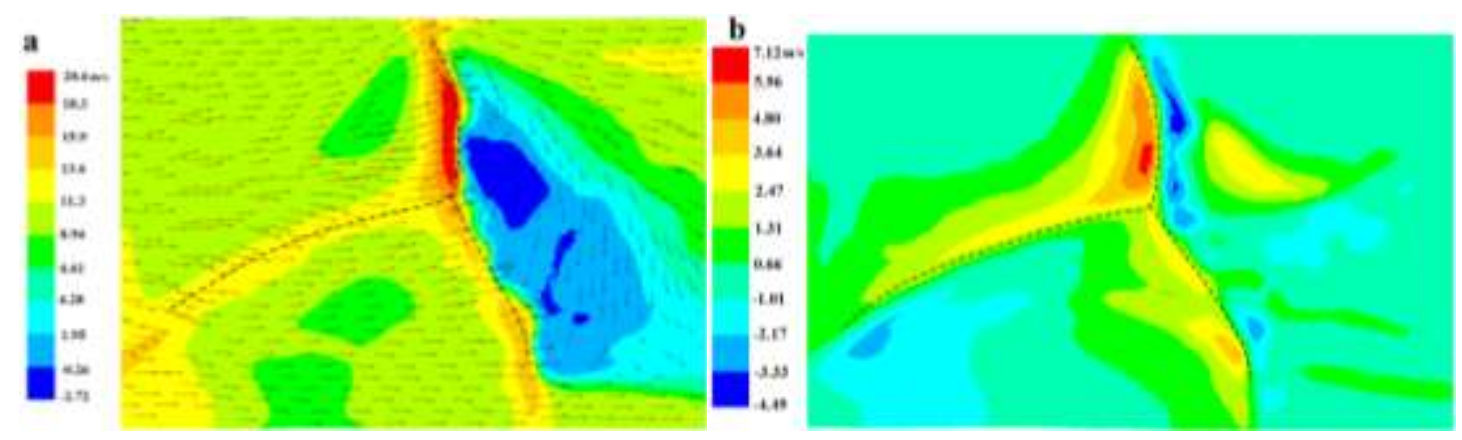

Figure 6

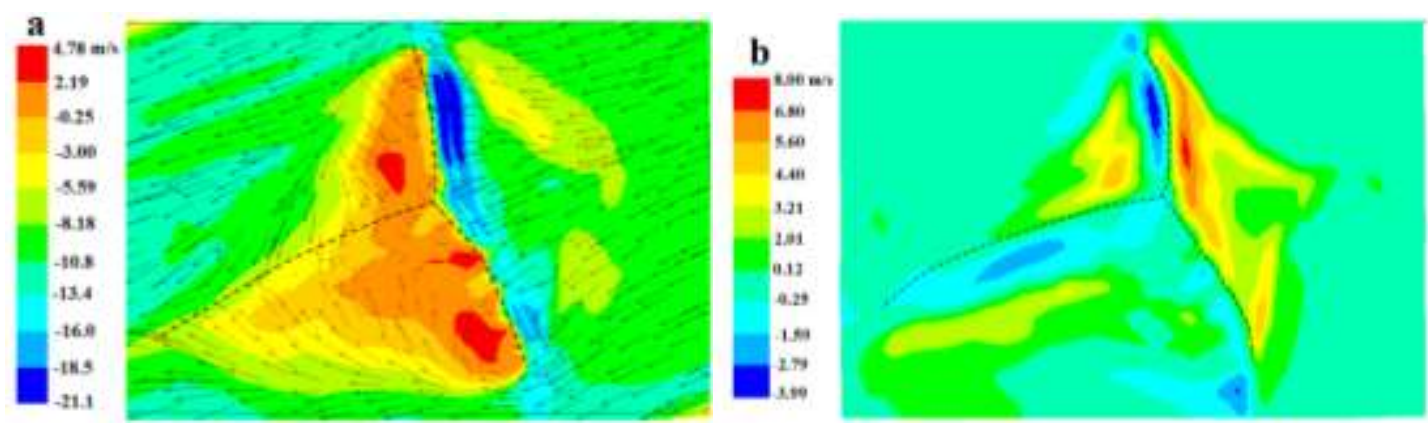


Figure 7
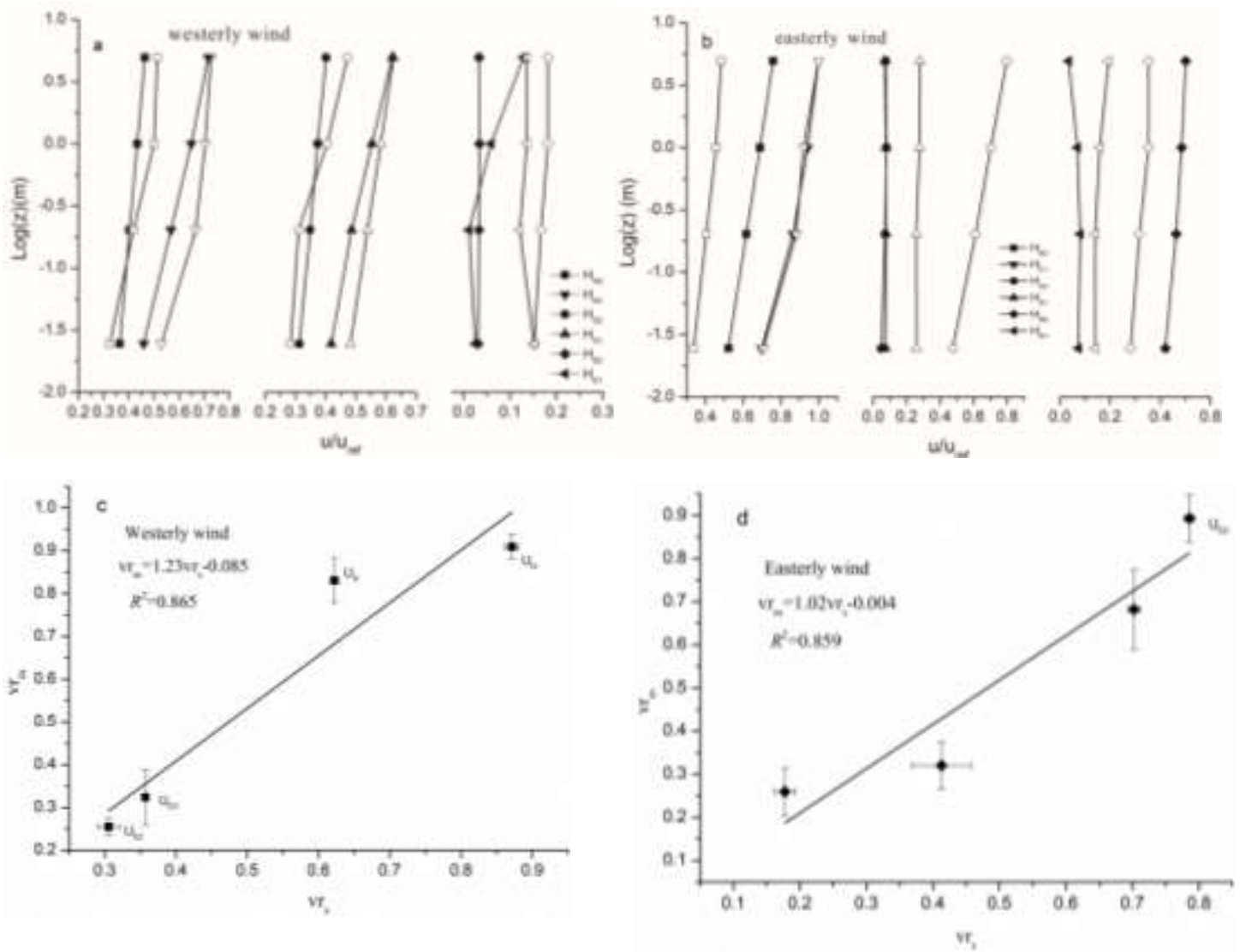
Table 1 Calculated local order accuracy (p) and fine-grid convergence indexes $\left(\mathrm{GCI}^{21}{ }_{\text {fine }}\right)$ for horizontal velocities in $\mathrm{HOBO}$ measurement sites (take thoes in westerly wind an eample). $\mathrm{N}$ is the total number of cells used for the computations and $\mathrm{u}_{\mathrm{x}}$ is the horizontal velocity in the $\mathrm{x}$-axis at a height of $2 \mathrm{~m}$ above the surface.

\begin{tabular}{llllllll}
\hline & $\mathrm{H}_{\mathrm{N} 2}$ & $\mathrm{H}_{\mathrm{N} 1}$ & \multicolumn{1}{c}{$\mathrm{H}_{\mathrm{T}}$} & $\mathrm{H}_{\mathrm{E} 2}$ & $\mathrm{H}_{\mathrm{E} 3}$ & $\mathrm{H}_{\mathrm{S} 1}$ & $\mathrm{H}_{\mathrm{S} 2}$ \\
\cline { 2 - 8 } & & & $\mathrm{N}_{1}=8066767$, & $\mathrm{N}_{2}=2646015$, & $\mathrm{N}_{3}=867937$ & & \\
\hline $\mathrm{u}_{\mathrm{x} 1}$ & 8.3359 & 13.4876 & 18.3624 & 3.5518 & 0.6195 & 11.5804 & 7.4715 \\
$\mathrm{u}_{\mathrm{x} 2}$ & 8.2518 & 13.3775 & 18.2459 & 3.4711 & 0.6145 & 11.4903 & 7.3913 \\
$\mathrm{u}_{\times 3}$ & 8.0718 & 13.0715 & 18.0598 & 3.2960 & 0.6032 & 11.1313 & 7.1955 \\
$\mathrm{p}$ & 2.05 & 2.75 & 1.26 & 1.97 & 2.21 & 3.72 & 2.40 \\
$\mathrm{GCI}^{21}{ }_{\text {fine }}$ & $1.04 \%$ & $0.53 \%$ & $1.25 \%$ & $2.59 \%$ & $0.74 \%$ & $0.29 \%$ & $0.87 \%$ \\
\hline
\end{tabular}


Table 2 the mean $\left(\mathrm{D}_{\mathrm{m}}\right)$ and standard deviations $\left(\mathrm{SD}_{\mathrm{m}}\right)$ the measured wind direction as well as the simulated wind direction (Ds) in both cases of W and ENE winds. Two repective measurent sites at the dune toe and upper one-third section were selcted for comparison.

\begin{tabular}{cccccccc}
\hline Wind & Comparison & & & & & \\
direction & parameters & $\left.\mathrm{H}_{\mathrm{E} 2}{ }^{\circ}\right)$ & $\mathrm{H}_{\mathrm{E} 1}$ & $\mathrm{H}_{\mathrm{N} 2}$ & $\mathrm{H}_{\mathrm{N} 1}$ & $\mathrm{H}_{\mathrm{S} 2}$ & $\mathrm{U}_{\mathrm{T}}$ \\
\hline \multirow{2}{*}{$\mathrm{W}$} & $\mathrm{D}_{\mathrm{m}}$ & 41.2 & 35.9 & 246.9 & 283.1 & 296.2 & 258.1 \\
& $\mathrm{SD}_{\mathrm{m}}$ & 19.3 & 19.8 & 4.8 & 3.8 & 9.3 & 5.5 \\
& $\mathrm{Ds}$ & 15 & 30 & 245 & 270 & 295 & 260 \\
\cline { 2 - 8 } $\mathrm{ENE}$ & $\mathrm{D}_{\mathrm{m}}$ & 52.6 & 67.5 & 282.2 & 298.2 & 143.6 & 217.2 \\
& $\mathrm{SD}_{\mathrm{m}}$ & 7.5 & 1.7 & 30.7 & 23.3 & 8.9 & 24.5 \\
& $\mathrm{Ds}$ & 60 & 60 & 300 & 325 & 150 & 215 \\
\hline
\end{tabular}

